\title{
Evaluation of turmeric-mung bean intercrop productivity through competition functions
}

\author{
Mohammad R. ISLAM ${ }^{1}$, Mohammad R. ALAM ${ }^{2}$, Ayman EL SABAGH ${ }^{3 *}$, Celaleddin BARUTÇULAR ${ }^{4}$, Disna \\ RATNASEKERA $^{5}$, Ferhat KIZILGEÇI ${ }^{6}$, M. Sohidul ISLAM ${ }^{7}$
}

Received January 29, 2018; accepted March 06, 2018.

Delo je prispelo 29. januarja 2018, sprejeto 06. mareca 2018.

\begin{abstract}
An intercropping experiment was conducted with varying combinations of turmeric and mung bean to find out the efficacy of productivity and economic return through competition functions. Treatments were evaluated on the basis of several competition functions, such as land equivalent ratio (LER), aggressiveness, competitive ratio (CR), monetary advantage index (MAI) and system productivity index (SPI). Results showed that rhizome yields of turmeric were higher in intercropping system than in mono crop. It indicated that intercropping of mung bean did not affect the rhizome yield of turmeric. However, turmeric $(100 \%)+3$ row mung bean $(100 \%)$ in between turmeric lines intercropping system exhibited maximum yield of both the crops as well as turmeric equivalent yield, LER, competitive indices values, SPI and MAI (Tk. 2,44,734.46 ha ${ }^{-1}$ ) compared to the other intercropping combinations and the mono crops. Aggressiveness of intercrop indicated dominance of turmeric over mung bean in all the combinations except turmeric $(100 \%)+1$ row mung bean $(33 \%)$. Competition functions of intercroping suggested beneficial association of turmeric and mung bean crops. The study revealed that mung bean could be introduced as intercrop with turmeric without hampering rhizome yield with higher benefit additionally increasing mung bean production area.
\end{abstract}

Key words: competition functions; economics; intercropping; turmeric; mung bean

\section{IZVLEČEK}

\section{OVREDNOTENJE PRIDELKA KOMBINIRANEGA GOJENJA KURKUME IN ZLATE VINJE GLEDE NA MEDSEBOJNO KOMPETICIJIO}

Povečanje učinkovitosti izrabe kmetijskih površin za večji pridelek je pomembno za prehranjevanje naraščajoče človeške populacije. Medsadnja kurkume $\mathrm{v}$ posevke zlate vinje (zelenega mungo fižola, Vigna radiata (L.) R. Wilczek) V optimalnih gostotah lahko poveča učinkovitost izrabe površin. Ekvivalent zemljišča (LER) je bil večji od $1 \mathrm{v}$ vseh sistemih mešanega gojenja. Poskus $\mathrm{z}$ mešanim gojenjem omenjenih poljščin je bil izveden v sezonah 2014 in 2015 z različnimi kombinacijami kurkume in zlate vinje na Regional Agricultural Research Station, Bangladesh Agricultural Research Institute, Ishwardi, Pabna, Bangladesh. Namen raziskave je bil ugotoviti učinkovitost in gospodarnost takšne pridelave $\mathrm{v}$ povezavi s tekmovalnostjo med obema poljščinama. Poskus je temeljil na naključnem bločnem razporedu s tremi ponovitvami. Obravnavanja so bila ovrednotena na osnovi različnih kompeticijskih funkcij kot so ekvivalent zemljišča (LER), agresivnost, kompeticijsko razmerje (CR), denarni indeks (MAI) in sistemski produktivnostni indeks (SPI). Rezultati so pokazali, da je bil pridelek korenik kurkume večji v vseh sistemih z medposevki kot $\mathrm{v}$ čisti sadnji. Pokazali so tudi, da kombinirano gojenje $z$ zlato vinjo ni povzročilo zmanjšanja pridelka korenik kurkume. Površine z vrstami čiste kurkume $(100 \%)$, kombiniranimi s trovrstnimi pasovi zlate vinje $(100 \%)$ so imele večji pridelek obeh poljščin kot tudi največje vrednosti za ekvivalent pridelka, LER, kompeticijski indeks, SPI in MAI (Tk. 2,44,734.46 $\mathrm{ha}^{-1}$ ) za kurkumo $\mathrm{v}$ primerjavi $\mathrm{z}$ drugimi sistemi mešanega gojenja in čistimi kulturami. Analiza agresivnosti pri različnih kombinacijah mešanega gojenja je pokazala prevlado kurkume nad zlato vinjo v vseh kombinacijah, razen v sistemu, kjer je bil nasad kurkume $(100 \%)$, kombiniran s po eno vrsto zlate vinje (33\%). Kompeticijske funkcije mešanih načinov gojenja so pokazale, da je glede na pozitiven učinek smiselno kombinirati omenjeni poljščini. Raziskava je pokazala, da bi se zlata vinja lahko uvedla kot medkultura kurkume, ne da bi zmanjašala pridelek njenih korenik, hkrati pa bi to predstavljalo dodatno možnost povečanja površin za pridelavo zlate vinje.

Ključne besede: kompeticijske funkcije; gospodarnost; medposevki; kurkuma; zlata vinja

\footnotetext{
1 Agronomy Division, Regional Agricultural Research Station, BARI, Ishwardi, Pabna, Bangladesh

2 On Farm Research Division, BARI, Pabna, Bangladesh

3 Department of Agronomy, Faculty of Agriculture, Kafrelsheikh University, Egypt

4 Department of Field Crops, Faculty of Agriculture, Cukurova, Turkey

5 Department of Agricultural Biology, Faculty of Agriculture, University of Ruhuna, Sri Lanka

6 Department of Field Crops, Faculty of Agriculture, Şırnak University, Şırnak, Turkey

7 Department of Agronomy, Hajee Mohammad Danesh Science and Technology University, Bangladesh
} 


\section{INTRODUCTION}

Turmeric (Curcuma longa L.) belongs to the family Zingiberaceae is one of the important tropical and subtropical rhizomatous species widely cultivated in Asia including Bangladesh. About 8307 hectares of land remain under turmeric cultivation in Pabna, Rajshahi, Faridpur, Jessore, Kushtia districts which were $37 \%$ of the total turmeric cultivation in Bangladesh (BBS, 2011). It is a long duration crop remains under field about 270-300 days. However, adoption of long duration turmeric varieties by cultivators poses a threat to some popular and time demanding traditionally grown pulse crop like mung bean in this region.

In Bangladesh, mung bean (Vigna radiata (L.) R. Wilczek) is a significant seed legume among pulses. It is widely cultivated in the worldwide for its' high content of protein in seeds (Hasan et al., 2017). Moreover, being a leguminous crop mung bean improves soil fertility through fixation of atmospheric nitrogen and provides additional yield advantages to the companion crop, which may contribute to gross return. It also performs well in a low-input intercropping system with non-legume and provides nitrogen, consequently the companion crop can grow faster and therefore improve yield (Esmaeilia et al., 2011).

The efficient use of natural and biological cycles such as nitrogen fixation by legumes may stimulate yield of the non-legume crops in an intercropped system (Hauggaard-Nielsen et al., 2001). In addition, mung bean supply 56, 61 and $67 \mathrm{~kg} \mathrm{~N}$ under low, moderate and high nutrient level, respectively (Mian, 2008). Ability to tolerate shading is one additional advantage of turmeric in intercropping systems. It is reported that higher fresh turmeric yield was obtained in intercropping system than mono cropping in open sunlight due to shady condition in India (Joyachandran et al., 1991). Furthermore, after planting of turmeric (rhizome), it takes 60 to 70 days to $100 \%$ emergence. During this period, farmers can easily grow short duration mung bean (65-75 days) crop in association with turmeric for higher benefit. In Bangladesh, majority of the farmers in farming community are small holders having 0.02-1.01 hectares of cultivated lands which also shrinking progressively (MOA, 2014).

In such background, intercropping offers the higher potentials of yield enhancement relative to mono cropping through yield stability and improved yield in tropical and sub-tropical areas (Nazir et al., 2002; Malik et al., 2002; Bhatti, 2005). Therefore, the way out is to grow the mung bean as an intercrop without losing turmeric production. However, studies on mung beanturmeric intercropping are not much available. The competition functions viz land equivalent ratio (LER), relative crowding coefficient $(\mathrm{K})$, competitive ratio (CR), aggressiveness, monetary advantage index (MAI) and system productivity index (SPI) have been developed to describe the competition and possible economic advantages of intercropping systems (Banik et al., 2000 ; Ghosh, 2004; Yilmaz et al., 2008; Midya et al., 2005; Oseni et al., 2010).

The extreme increase in population in Bangladesh needs to maximize the total production of legume crops for overcome the deficiency of protein through cultivation in the newly lands (Rahman et al., 2017). The importance of pulses is very much pertinent for food and improving the farm-family income in order to ensure food security, nutritional security and economic security (Islam et al., 2017). Hence, this study was undertaken to find out the efficacy of productivity and economic return of intercropping mung bean with turmeric through different competition functions.

\section{MATERIALS AND METHODS}

\subsection{Experimental Site}

The experiment was conducted at the Regional Agricultural Research Station (RARS), BARI, Ishwardi, Pabna, Bangladesh during 2014 and 2015 to find out the efficiency of productivity and economic return from intercropping mung bean with turmeric through competition functions.

\subsection{Data sources and treatments}

The treatments viz. $\mathrm{T}_{1}=$ Turmeric $(100 \%)+1$ row mung bean $(33 \%)$ in between turmeric lines; $\mathrm{T}_{2}=$ Turmeric $(100 \%)+2$ row mung bean $(67 \%)$ in between turmeric lines; $\mathrm{T}_{3}=$ Turmeric $(100 \%)+3$ row mung bean $(100 \%)$ in between turmeric lines; $\mathrm{T}_{4}=$ Turmeric $(100 \%)+$ mung bean broadcast $(100 \%)$ in between turmeric lines; $\mathrm{T}_{5}=$ only turmeric as a mono crop, and $\mathrm{T}_{6}=$ only mung bean as a mono crop were used. The experiment was laid out in a randomized complete block design with three replications. The unit plot size was $4.5 \mathrm{~m} \times 4 \mathrm{~m}$. Turmeric was established as main crop and mung bean was used as the intercrop in the study. Mung bean was intercropped in between turmeric row at 33, 67 and $100 \%$ population densities. Turmeric ('BARI Halud-4') and mung bean ('BARI mung-6') were planted/sown on 22 March 2014 and 
2015, respectively. Turmeric 'BARI Halud-4' was harvested on 31 and 28 December 2014 and 2015, respectively. Mung bean was harvested on 20-30 May in both years, respectively. Except broadcasting, mung bean seeds were sown keeping row spacing $30 \mathrm{~cm}$ following continuous seeding. The mono crop of turmeric and intercrops was fertilized with 140-54-117 $\mathrm{kg} \mathrm{ha}^{-1}$ of N-P-K with $5 \mathrm{tha}^{-1}$ cow dung. In case of intercropping mung bean with turmeric full amount of $\mathrm{P}, 1 / 4 \mathrm{~N}$ and $1 / 4$ of $\mathrm{K}$ with $5 \mathrm{tha}^{-1}$ cow dung were applied during final land preparation. Rest $\mathrm{N}$ and $\mathrm{K}$ were applied three equal components at 70, 100 and 120 days after planting/sowing. For mung bean mono crop treatment, fertilizer was applied at $20-20-20 \mathrm{~kg} \mathrm{ha}^{-1}$ of N-P-K. All fertilizers were applied as basal at final land preparation. Weeding and other intercultural operations were done as per requirement of the crops. After emergence, mung bean was thinned out for keeping plant to plant distance of $5 \mathrm{~cm}$. Earthing up of turmeric was done after harvesting mung bean (100 days after planting).

\subsection{Measurements and Data analysis}

Data on yield and yield contributing characteristics were recorded and statistically analysed. The mean values were adjudged by LSD (0.05). Turmeric equivalent yield (TEY) was converted by converting yield of intercrops on the basis of presenting market price of individual crop following the formula:

$\mathrm{TEY}=$ Yield of intercrop turmeric $+\frac{\mathrm{Yi} \times \mathrm{Pi}}{\text { Price of mungbean }}$ Where, $\mathrm{Yi}=$ Yield of intercrop, and $\mathrm{Pi}=$ Price of intercrop.

The important tool that agricultural researchers commonly use to assess the relative advantage of intercropping compared to sole crops is the land equivalent ratio (LER) (Mead and Willey, 1980). If the value of LER shows $>1$, the intercropping favors the growth and yield of the species. When LER demonstrate $<1$, the intercropping negatively effects the growth and yield of crops grown in mixtures (Caballero et al. 1995). It was calculated for each proportion on a plot basis using the total land equivalent ratio (LER):

$\mathrm{LER}=\mathrm{RY}_{\mathrm{t}}+\mathrm{RY}_{\mathrm{i}}=\frac{\mathrm{T}_{\mathrm{IY}}}{\mathrm{T}_{\mathrm{SY}}}+\frac{\mathrm{M}_{\mathrm{IY}}}{\mathrm{M}_{\mathrm{SY}}}$

Where, $\mathrm{RY}_{\mathrm{t}}=$ Relative yield of turmeric (main crop),

$\mathrm{RY}_{\mathrm{i}}=$ Relative yield of intercrops (mung bean),

$\mathrm{T}_{\mathrm{IY}}=$ Intercrop yield of turmeric,

$\mathrm{T}_{\mathrm{SY}}=$ Sole crop yield of turmeric,

$\mathrm{M}_{\mathrm{IY}}=$ Intercrop yield of mung bean, and

$\mathrm{M}_{\mathrm{SY}}=$ Sole crop yield of mung bean

Replacement value of intercropping (RVI) is a slightly more complex tool that used to measure for economic feasibility of intercropping or mixed cropping (Moseley, 1994) which computed as:

$\mathrm{RVI}=\frac{\mathrm{aP}_{1}+\mathrm{bP}_{2}}{\mathrm{aM}_{1}-\mathrm{C}}$

Where, $\mathrm{P}_{1} \& \mathrm{P}_{2}$ are the yield of intercrops and $\mathrm{a}$ and $\mathrm{b}$ are the respective prices of these crops. $\mathrm{M}_{1}$ is the yield and $\mathrm{C}$ is the input cost of the primary (main) crop in sole stand.

The entire the competition indices MAI give an indication of the economic advantage of the intercropping system. The higher the MAI value the more profitable is the cropping system (Ghosh 2004). MAI was calculated as described by Ali and Mishra (1993) as follows:

MAI $=$ Value of combined intercrop yield $\times($ LER 1)/LER

Where, MAI $=$ Monetary advantage index, LER $=$ Land equivalent ratio

Competitive ratio (CR) gives better measure of competitive ability of the crops as well as evaluation whether the association of the two component crops is beneficial or not (Mahapatra, 2011). It measures the ratio of individual LERs of the two component crops and the proportion in which they were sown in the mixture. The competitive ratio (CR) among different combinations was calculated using the following formula (Willey, 1990):

$\mathrm{CR}=\frac{\text { LER of } \operatorname{crop}(\mathrm{a})}{\text { LER of } \operatorname{crop}(\mathrm{b})}$

Agressivity (A) indicates the relative yield increase in "a" crop is greater than of "b" crop in an intercropping system (McGilchrist 1965). Aggressiveness was determined according to Willey and Rao (1980) using mean grain yield values of treatments averaged across years and replications as:

Aggressiveness of turmeric (Aab) $=\frac{Y_{a b}}{Y_{a a} \times Z_{a b}}-\frac{Y_{b a}}{Y_{b b} \times Z_{b a}}$

Aggressiveness of mung bean (Aba) $=\frac{Y_{\mathrm{ba}}}{\mathrm{Y}_{\mathrm{bb}} \times \mathrm{Z}_{\mathrm{ba}}}-\frac{\mathrm{Y}_{\mathrm{ab}}}{\mathrm{Y}_{\mathrm{aa}} \times \mathrm{Z}_{\mathrm{ab}}}$

Where,

$\mathrm{Y}_{\mathrm{ab}}=$ Intercropped yield of turmeric,

$\mathrm{Y}_{\mathrm{ba}}=$ Intercropped yield of mung bean,

$\mathrm{Y}_{\mathrm{aa}}=$ Mono crop yield of turmeric, 
$\mathrm{Y}_{\mathrm{bb}}=$ Mono crop yield of mung bean,

$\mathrm{Z}_{\mathrm{ab}}=$ Sown proportion of turmeric, and

$\mathrm{Z}_{\mathrm{ba}}=$ Sown proportion of mung bean.

The system productivity index (SPI) was calculated based on (Odo, 1991):
System productivity index $(\mathrm{SPI})=\frac{\mathrm{S}_{\mathrm{a}}}{\mathrm{S}_{\mathrm{b}}} \mathrm{Y}_{\mathrm{b}}+\mathrm{Y}_{\mathrm{a}}$

Where,

$\mathrm{S}_{\mathrm{a}}=$ Mean yield of turmeric in Mono culture,

$\mathrm{S}_{\mathrm{b}}=$ Mean yield of mung bean in Mono culture,

$\mathrm{Y}_{\mathrm{a}}=$ Mean yield of turmeric in mixed culture,

$Y_{b}=$ Mean yield of mung bean in mixed culture.

\section{RESULTS AND DISCUSSION}

\subsection{Yield and yield attributes of turmeric}

Rhizome yield and yield attributes of turmeric were significantly varied among the intercropping treatments (Table 1). It was evident that the entire yield and yield attributes in the intercropping treatments increased with the increasing of mung bean population. This might be due to the $\mathrm{N}$ fixation ability of the legume which lead an improvement of turmeric (rhizome) yield as well as yield attributes. Values of yield contributing characters were maximum under turmeric $(100 \%)+3$ row mung bean $(100 \%)$ in between turmeric lines intercropping system compared to other intercropping systems and mono cropping. Our data clearly showed that turmeric showed yield ranged of 17.52-20.01 $\mathrm{t} \mathrm{ha}^{-1}$ in intercropping systems, which was higher than that of mono culture $\left(17.43 \mathrm{t} \mathrm{ha}^{-1}\right)$. However, the maximum value was found under turmeric $(100 \%)+3$ row mung bean $(100 \%)$ in turmeric lines intercropping system. The results further revealed that intercropping mung bean with turmeric did not hamper the normal growth of turmeric but it significantly enhanced the growth and development, which lead the highest rhizome yield in mung bean-turmeric intercropping system compared to cultivation of turmeric alone. These results are in agreement with the findings of (Joyachandran et al., 1991) who reported that higher fresh turmeric yield was obtained in intercropping systems than mono crop (in open sunlight) due to shady condition. The rhizome yield increased up to $15 \%$ in intercropping systems than mono cropping of turmeric (Table 1).

Table 1: Yield and yield contributing characters of turmeric (pooled average of 2014 and 2015)

\begin{tabular}{cccccccc}
\hline Treatments & $\begin{array}{c}\text { Plant } \\
\text { height } \\
(\mathrm{cm})\end{array}$ & $\begin{array}{c}\text { Number of } \\
\text { mother } \\
\text { rhizomes/ } \\
\text { plant }\end{array}$ & $\begin{array}{c}\text { Number of } \\
\text { fingers/ } \\
\text { plant }\end{array}$ & $\begin{array}{c}\text { Mass of mother } \\
\text { rhizome/plant } \\
(\mathrm{g})\end{array}$ & $\begin{array}{c}\text { Mass of } \\
\text { fingers/plant } \\
(\mathrm{g})\end{array}$ & $\begin{array}{c}\text { Rhizome } \\
\text { yield (t } \\
\left.\text { ha }^{-1}\right)\end{array}$ & $\begin{array}{c}\text { Rhizome } \\
\text { yield }(\%) \\
\text { increased over } \\
\text { sole turmeric }\end{array}$ \\
\hline $\mathrm{T}_{1}$ & 119.47 & 6.06 & 15.78 & 180.18 & 363.16 & 17.52 & 0.52 \\
$\mathrm{~T}_{2}$ & 120.13 & 7.18 & 16.49 & 190.19 & 371.09 & 18.16 & 4.19 \\
$\mathrm{~T}_{3}$ & 124.69 & 7.40 & 17.49 & 241.59 & 409.85 & 20.01 & 14.80 \\
$\mathrm{~T}_{4}$ & 123.96 & 7.51 & 17.55 & 238.29 & 411.13 & 19.74 & 13.25 \\
$\mathrm{~T}_{5}$ & 119.16 & 5.39 & 15.16 & 163.34 & 349.75 & 17.14 & 1.18 \\
$\mathrm{LSD}(0.05)$ & 4.48 & 0.90 & 0.90 & 15.10 & 3.68 & 5.19 & - \\
$\mathrm{CV}(\%)$ & 3.01 & 10.94 & 4.46 & 6.09 & & \\
\hline
\end{tabular}

\subsection{Yield and yield attributes of mung bean}

Yield and yield attributes of mung bean were significantly influenced by different intercropping system (Table 2). The longest plants $(52.42 \mathrm{~cm})$ was recorded from turmeric $(100 \%)+3$ row mung bean $(100 \%)$ in between turmeric lines intercropping system $\left(\mathrm{T}_{3}\right)$. The shortest mung bean plants were observed in the treatment of one row mung bean between two turmeric lines $\left(\mathrm{T}_{1}\right)$. The maximum number of pods per plant (15.16) was recorded in the turmeric $(100 \%)+1$ row mung bean (100\%) in between turmeric lines intercropping system. Reduction in number of pods per plant was found with increased plant population of mung bean. Similar results were found in case of pod length, seeds/pod and 1000-seed mass. Mung bean produced the maximum seed yield in mono culture (1.08 $\mathrm{t} \mathrm{ha}^{-1}$ ). Higher mung bean seeds were harvested from the higher percentage of mung bean populations in the intercrops resulted the highest seed yield of mung bean $\left(1.05 \mathrm{t} \mathrm{ha}^{-1}\right)$ in the turmeric $(100 \%)+3$ row mung 
bean $(100 \%)$ in between turmeric lines intercropping system $\left(\mathrm{T}_{3}\right)$ than other combinations. The lowest seed yield $\left(0.51 \mathrm{t} \mathrm{ha}^{-1}\right)$ was recorded in turmeric $(100 \%)+1$ row mung bean $(100 \%)$ in between turmeric lines intercropping system $\left(\mathrm{T}_{1}\right)$, probably due to the lowest plant population of mung bean per unit area. Mung bean showed $3 \%$ to $53 \%$ higher yield in mono cropping systems as compared to their corresponding intercropping systems.

Table 2: Yield contributing characters and yield of mung bean (pooled average of 2014 and 2015)

\begin{tabular}{cccccccc}
\hline Treatments & $\begin{array}{c}\text { Plant } \\
\text { height } \\
(\mathrm{cm})\end{array}$ & $\begin{array}{c}\text { Pods/ plant } \\
\text { (no.) }\end{array}$ & $\begin{array}{c}\text { Pod length } \\
(\mathrm{cm})\end{array}$ & $\begin{array}{c}\text { Seeds/pod } \\
\text { (no.) }\end{array}$ & $\begin{array}{c}\text { 1000-seed } \\
\text { mass }(\mathrm{g})\end{array}$ & $\begin{array}{c}\text { Yield (t ha } \\
{ }^{-} \text {) }\end{array}$ & $\begin{array}{c}\text { Yield decreased (\%) } \\
\text { over sole sesame }\end{array}$ \\
\hline $\mathrm{T}_{1}$ & 45.90 & 15.16 & 9.52 & 11.65 & 51.11 & 0.51 & 52.78 \\
$\mathrm{~T}_{2}$ & 48.88 & 13.61 & 8.68 & 9.98 & 50.68 & 0.72 & 33.33 \\
$\mathrm{~T}_{3}$ & 52.42 & 13.36 & 8.32 & 9.79 & 50.62 & 1.05 & 2.78 \\
$\mathrm{~T}_{4}$ & 50.53 & 12.10 & 8.15 & 9.59 & 46.99 & 1.00 & 7.41 \\
$\mathrm{~T}_{5}$ & & & & & & & - \\
$\mathrm{T}_{6}$ & 47.16 & 12.35 & 8.33 & 9.76 & 50.45 & 1.08 & - \\
$\mathrm{LSD}_{(0.05)}$ & 3.73 & 1.28 & 0.914 & 1.14 & 2.00 & 0.04 & - \\
$\mathrm{CV}_{(\%)}$ & 6.23 & 7.84 & 8.68 & 9.19 & 3.27 & 4.12 & - \\
\hline
\end{tabular}

$\mathrm{T}_{1}=$ Turmeric $100 \%+1$ line mung bean (33\%) in between two turmeric lines; $\mathrm{T}_{2}=$ Turmeric $100 \%+2$ lines mung bean $(67 \%)$ in between two turmeric lines; $\mathrm{T}_{3}=$ Turmeric $100 \%+3$ lines mung bean $(100 \%)$ in between two turmeric lines; $\mathrm{T}_{4}=$ Turmeric $100 \%+$ mung bean broadcast $(100 \%)$ in between two turmeric lines; $\mathrm{T}_{5}=$ Sole Turmeric and $\mathrm{T}_{6}=$ Sole mung bean

\subsection{Turmeric equivalent yield (TEY)}

TEY was referred to total productivity and it ranged from 19.05 to $23.16 \mathrm{t} \mathrm{ha}^{-1}$ in intercropping system, which was higher compared to mono cropping treatments (Table 3) indicating higher biomass production and efficient land use and recourse availability under intercropping than mono cropping. However, the highest TEY was recorded with turmeric
$(100 \%)+3$ row mung bean $(100 \%)$ in between turmeric lines intercropping system $\left(\mathrm{T}_{3}\right)$. The total productivity increase of $9 \%$ to $33 \%$ over mono cropping turmeric where turmeric $(100 \%)+3$ row mung bean $(100 \%)$ in between turmeric lines intercropping combination increase the highest total productivity $(33 \%)$.

Figure 3: Economics of intercropping mung bean with turmeric (average of two years)

\begin{tabular}{cccccc}
\hline Treatments & TEY $\left(\mathrm{t} \mathrm{ha}^{-1}\right)$ & Gross return $\left(\mathrm{Tk} \mathrm{ha}^{-1}\right)$ & $\begin{array}{c}\text { Total cost } \\
\left(\mathrm{Tk} \mathrm{ha}^{-1}\right)\end{array}$ & $\begin{array}{c}\text { Gross margin } \\
\left(\mathrm{Tk} \mathrm{ha}^{-1}\right)\end{array}$ & BCR \\
\hline $\mathrm{T}_{1}$ & 19.05 & 381000 & 149014 & 231986 & 2.56 \\
$\mathrm{~T}_{2}$ & 20.32 & 406400 & 151714 & 254686 & 2.68 \\
$\mathrm{~T}_{3}$ & 23.16 & 463200 & 154414 & 308786 & 3.00 \\
$\mathrm{~T}_{4}$ & 22.74 & 454800 & 154564 & 300236 & 2.94 \\
$\mathrm{~T}_{5}$ & 17.43 & 348600 & 137064 & 211536 & 2.54 \\
$\mathrm{~T}_{6}$ & 3.24 & 64800 & 30260 & 34540 & 2.14 \\
\hline
\end{tabular}

Market price: Turmeric: TK $20 \mathrm{~kg}^{-1}$ and Mung bean: Tk $60 \mathrm{~kg}^{-1}$

\subsection{Economics}

In the present study, all the intercrop combinations showed higher monetary return than mono crops (Table 3). The maximum gross return (Tk. 4, 63,200 ha ${ }^{-1}$ ) was found to be in turmeric $(100 \%)+3$ row mung bean $(100 \%)$ in between turmeric lines intercropping system $\left(\mathrm{T}_{3}\right)$. Mono crop of mung bean showed the lowest gross return $\left(\mathrm{Tk} .64,800 \mathrm{ha}^{-1}\right)$. The highest cost of cultivation was observed under all intercropping systems while 
maximum was observed in turmeric $100 \%+$ mung bean broadcast $(100 \%)$ in between two turmeric lines intercropping system. It was mainly due to more cost in extra labour required for sowing, harvesting, and other agronomic operations of two crops. The highest benefit cost ratio (BCR) was obtained (3.00) in turmeric $(100 \%)+3$ row mung bean $(100 \%)$ in between turmeric lines intercropping system compared to all other combinations.

\subsection{LER, RVI, MAI, SPI and Aggressiveness of turmeric-mung bean intercrop}

The outcome of different intercropping systems on LER, RVI, MVI, SPI and aggressiveness are presented in Table 4. The LER is the relative area of mono crop required to produce the yield achieved in intercropping (Khan, 1988). The LER values were $>1.0$ for all the intercropping systems showed the efficacy of all intercropping systems. The increased value of LER over 1 (unity) indicated more land utilization facility in intercropping over actual mono cropping land (Mian, 2008). It also indicated yield advantage of intercropping over mono cropping with regard to the use of environmental resources for plant growth. The LER of different intercrop combinations ranged from 1.48 to 2.12 indicating $48-112 \%$ yield increase by intercropping. The maximum LER value (2.12) was found in turmeric $(100 \%)+3$ row mung bean $(100 \%)$ in between turmeric lines intercropping system. The LER value was increased proportionately in both crops in the different intercropping system. The result revealed that LER>1.00 in intercropping rendered better productivity than their mono crops.

RVI is a way to determine the economic advantage of intercropping. The maximum RVI (2.19) was observed in turmeric $(100 \%)+3$ row mung bean $(100 \%)$ in between turmeric lines intercropping system (Table 4) implying that the farmers who practice intercropping of turmeric $(100 \%)+3$ row mung bean $(100 \%)$ in between turmeric lines will be making $119 \%$ profit more than the farmers who are practicing monocropping of these crops. Therefore, the reason to popular intercropping systems among farmers is wellunderstood.

Table 4: Land equivalent ratio (LER), replacement value of intercropping (RVI), monetary advantage index (MAI), system productivity index (SPI) and aggressivity of mung bean-turmeric intercropping system (average of two years)

\begin{tabular}{c|c|c|c|c|c|c}
\hline Treatments & LER & RVI & $\begin{array}{c}\text { MAI } \\
\left(\text { Tk. ha }{ }^{-1}\right)\end{array}$ & SPI & \multicolumn{2}{|c}{ Aggressivity } \\
\cline { 6 - 8 } & & & & & Turmeric & Mung bean \\
\hline $\mathrm{T}_{1}$ & 1.48 & 1.80 & 123112.04 & 25.75 & -0.43 & 0.43 \\
$\mathrm{~T}_{2}$ & 1.71 & 1.92 & 168537.27 & 29.78 & 0.05 & -0.05 \\
$\mathrm{~T}_{3}$ & 2.12 & 2.19 & 244734.46 & 36.96 & 0.18 & -0.18 \\
$\mathrm{~T}_{4}$ & 2.06 & 2.15 & 233857.71 & 35.88 & 0.21 & -0.21 \\
$\mathrm{~T}_{5}$ & 1.00 & 1.65 & - & - & - & - \\
$\mathrm{T}_{6}$ & 1.00 & 0.31 & - & - & - & - \\
\hline
\end{tabular}

MAI values were positive in all the intercropping systems. The result showed positive yield and economic advantages of the intercropping system over their mono cropping. The highest MAI (Tk. 2, 44,734.46 ha $\left.{ }^{-1}\right)$ ) was obtained in the turmeric $(100 \%)+3$ row mung bean $(100 \%)$ in between turmeric lines intercropping system, which implied that the combination was highly economical and advantageous (Table 4).

SPI standardized the yield of the secondary crop (mung bean) in terms of the primary crop (turmeric) and identified the combinations that utilized the growth resources effectively. The highest SPI (36.96) was found in turmeric $(100 \%)+3$ row mung bean $(100 \%)$ in between turmeric lines intercropping system over the other combinations and monoculture. Contrary, the lowest SPI (25.75) was observed in turmeric $(100 \%)+$ 1 row mung bean $(100 \%)$ in between turmeric lines intercropping system (Table 4). The results also revealed that mung bean in high densities $(100 \%)$, as in the intercropping with turmeric utilized resources more effectively over other combinations and thus had a higher SPI.

Aggressiveness is an important tool that measures the competitive ability of a crop when grown in association with another crop (Dhima et al., 2007). An aggressiveness value of zero indicates that the component crops are equally competitive. But the data regarding the aggressiveness values of turmeric and 
mung bean revealed that the component crops did not compete equally (Table 4). Negative sign of aggressiveness values for mung bean indicates the dominance of turmeric in all the intercropping systems except in turmeric $(100 \%)+1$ row mung bean $(100 \%)$ in between turmeric lines intercropping system, in which mung bean dominated the turmeric.

Table 5: Competitive ratio (CR) of turmeric and mung bean

\begin{tabular}{cccc}
\hline Treatments & CR of turmeric & CR of mung bean & Difference \\
\hline $\mathrm{T}_{1}$ & 2.13 & 0.47 & 0.92 \\
$\mathrm{~T}_{2}$ & 1.56 & 0.64 & 0.33 \\
$\mathrm{~T}_{3}$ & 1.18 & 0.85 & 0.41 \\
$\mathrm{~T}_{4}$ & 1.22 & 0.82 & - \\
$\mathrm{T}_{5}$ & - & - & -
\end{tabular}

$\mathrm{T}_{1}=$ Turmeric $100 \%+1$ line mung bean (33\%) in between two turmeric lines; $\mathrm{T}_{2}=$ Turmeric $100 \%+2$ lines mung bean $(67 \%)$ in between two turmeric lines; $\mathrm{T}_{3}=$ Turmeric $100 \%+3$ lines mung bean (100\%) in between two turmeric lines; $\mathrm{T}_{4}=$ Turmeric $100 \%+$ mung bean broadcast $(100 \%)$ in between two turmeric lines; $\mathrm{T}_{5}=\mathrm{Sole}$ Turmeric and $\mathrm{T}_{6}=$ Sole mung bean .

\subsection{Competitive ratio (CR)}

$\mathrm{CR}$ is an important way to measure the degree of competitiveness in which one crop compete with the others. The results of CR were higher in turmeric (1.182.13) than mung bean (0.47-0.85) indicating that turmeric was more competitive than mung bean in all intercropping systems. The highest $\mathrm{CR}$ value of turmeric was recorded in turmeric $(100 \%)+1$ row mung bean $(100 \%)$ in between turmeric lines intercropping system showing a decreasing trend with the mung bean proportion increases. This was due to more intra-species competition at higher population of mung bean. Similarly, the highest CR value of mung bean $(0.85)$ was found in turmeric $(100 \%)+3$ row mung bean $(100 \%)$ in between turmeric lines intercropping system exhibiting a decreasing trend with the increase of $\mathrm{CR}$ values of turmeric. Lower difference of CR values indicated better utilization of growth resources. However, turmeric $(100 \%)+3$ row mung bean $(100 \%)$ in between turmeric lines intercropping system produced higher productivity in terms of TEY (23.16 $\mathrm{t} \mathrm{ha}^{-1}$ ) with minimum CR difference of 0.33 (Table 5). The CR over 1 (unity) indicates the species as good competitor while less than 1 (unity) indicates the species as poor competitor when grown in intercropping (Jedel et al., 1998).

\section{CONCLUSIONS}

Our results confirmed that potential benefits of intercropping mung bean with turmeric especially for increasing cropping intensity, total productivity and economic return per unit land enhancing national food security against gradual declining cultivable land. Further, the results showed correlation on improving soil fertility by mung bean and sustaining crop productivity under intensive cropping systems. Moreover, the results encourage the farmers to grow long duration turmeric crop for getting higher economic return. The outcome of the results furthermore indicated that rhizome yield of turmeric was higher in intercropping system than in mono crop. However, turmeric $(100 \%)+3$ row mung bean $(100 \%)$ in between turmeric lines intercropping system gave maximum yield of both the crops as well as TEY, better land use efficiency, BCR and MAI. Therefore, turmeric $(100 \%)+3$ row mung bean $(100 \%)$ in between turmeric lines could be a better intercropping system. 


\section{REFERENCES}

Ali, M., Mishra, J. S. (1993). Intercropping of blackgram (Phaseolus mungo) and greengram $(P$. radiatus) with spring sunflower (Helianthus annuus). Indian Journal of Agricultural Sciences, 63(8), 493-495.

Banik, P., Sasmal, T., Ghosal, P. K., Bagchi, D. K. (2000). Evaluation of mustard (Brassica compestris var. toria) and legume intercropping under 1:1 and 2:1 row-replacement series systems. Journal of Agronomy and Crop Science, 185, 9-14. doi.org/10.1046/j.1439-037X.2000.00388.X

BBS (Bangladesh Bureau of Statistics). (2011). Statistical Year Book of Bangladesh. Statistics Division, Ministry of Planning, Government of the Peoples Republic of Bangladesh, Dhaka.

Bhatti, I. H. (2005). Agro-physiological studies on sesame-legume intercropping system in different geometric arrangements. $\mathrm{Ph}$. D. thesis, Department of Agronomy, University of Agriculture, Faisalabad, Pakistan.

Caballero, R., Goicoechea, E.L., Hernaiz, P. J. (1995). Forage yield and quality of common vetch and oat sown at varying seed ratios and seeding rates of common vetch. Field Crops Research, 41, 135-140. doi.org/10.1016/0378-4290 (94)00114-R

Dhima, K. V., Lithourgidis, A. S., Vasilakoglou, I. B., Dordas, C. A. (2007). Competition indices of common vetch and cereal intercrops in two seeding ratio. Field Crop Research, 100, 249-256. doi.org/10.1016/j.fcr.2006.07.008

Esmaeilia, A., Sadeghpourb, A., Hosseinia, S. M. B., Jahanzada, E., Chaichia, M. R., Hashem, M. (2011). Evaluation of seed yield and competition indices for intercropped barley (Hordeum vulgare) and annual medic (Medicago scutellata). International Journal of Plant Production, 5(4), 395-404. doi: 10.22069/ijpp.2012.749

Ghosh, P. K. (2004). Growth, yield, competition and economics of groundnut/cereal fodder intercropping systems in the semi-arid tropics of India. Field Crops Research, 88, 227-237. doi.org/10.1016/j.fcr.2004.01.015

Hasan, MD. K., Sabagh, A. EL., Sikdar, MD. S. I., Alam, MD. J., Ratnasekera, D., Barutçular, C., Islam, M.S. (2017). Comparative adaptable agronomic traits of black gram and mung bean for saline lands. Plant Archives, 17(1), 589-593.

Hauggaard-Nielsen, H., Ambus, P., Jensen, E. S. (2001). Interspecific competition, $\mathrm{N}$ use and interference with weeds in pea-barley intercropping. Field Crops Research, 70, 101-109. doi.org/10.1016/S0378-4290 (01)00126-5

Islam, M. S., EL Sabagh, A., Hasana, K., Akhter, M., Hasan Barutçulard, C. (2017). Growth and yield response of mung bean (Vigna radiata L.) as influenced by sulphur and boron application. Scientific Journal of Crop Science , 6(1), 153-160. doi: 10.14196/sjcs.v6i1.2383

Jedel, P. E., Helm, J. H., Burnett, P. A. (1998). Yield, quality and stress tolerance of barley mixture in central Alberta. Canadian Journal of Plant Science, 78, 429-436. doi.org/10.4141/P97-137

Joyachandran, B. K., Bari, M. M., Salam, M. A., Mannan, M. K., Mathew, K. P. (1991). Performance of turmeric/ginger under shade and open condition. Indian Coca, Arecanut and Spices Journal, 15(2), 40-42.

Khan, Z., Ahmed, S., Nazir, M. S. (1988). Land equivalent ratios, relative yields and relative yield totals of intercropped maize and soybean. Pakistan Journal of Agricultural Sciences, 9, 453-457.

Malik, M. A., Saleem, M. F., Sana, M., Aziz, A. (2002). Agro economic expression of different relay crops after rice harvest under conventional and zero tillage. International Journal of Agriculture and Biology, 4, 277-278.

Mahapatra, S. C. (2011). Study of Grass-Legume Intercropping System in Terms of Competition Indices and Monetary Advantage Index under Acid Lateritic Soil of India. American Journal of Experimental Agriculture, 1(1), 1-6. doi:10.5281/zenodo.8092

McGilchrist, C.A. (1965). Analysis of competition experiments. Biometrics, 21, 975-985. doi.org/10.2307/2528258

Mead, R., Willey, R.W. (1980). The concept of land equivalent ratio and advantages in yields for intercropping. Experimental Agriculture, 16, 217228. doi.org/10.1017/S0014479700010978

Mian, M. A. K. (2008). Performance of maize oriented cropping patterns under different nutrient management. Ph. D. Dissertation, Dept. Agron., Bangladesh Agril. Univ., Mymensingh. pp. 31-137.

Midya, A., Bhattacharjee, K., Ghose, S. S., Banik, P. (2005). Deferred seeding of blackgram (Phaseolus mungo L.) in rice (Oryza sativa L.) field on yield advantages and smothering of weeds. Journal of Agronomy and Crop Science, 191, 195-201. doi.org/10.1111/j.1439-037X.2005.00157.x 
Evaluation of turmeric-mung bean intercrop productivity through competition functions

MOA (Ministry of Agriculture). (2014). Hand Book of Agricultural Statistics, December 2007. Government of the Peoples Republic of Bangladesh. http://www.moa.gov.bd/statistics/ statistics.htm

Mosely, W. G. (1994). An equation for the replacement value of agroforestry. Agroforestry System, 26, 4752. doi: 10.1007/BF00705151

Nazir, M. S., Jabbar, A., Ahmad, I., Nawaz, S., Bhatti, I. H. (2002). Production potential and economics of intercropping in autumn-planted sugarcane. International Journal of Agriculture and Biology, 4, 140-142.

Odo, P. E. (1991). Evaluating short and tall sorghum varieties in mixtures with cowpea in Sudan Savanna of Nigeria: LER, grain yield and system productivity index. Experimental Agriculture, 27(4), 435- 441. doi.org/10.1017/S0014479700019426

Oseni, T. O. (2010). Evaluation of sorghum-cowpea intercrop productivity in savanna agro-ecology using competition indexes. Journal of Agricultural
Science, 2(3),

doi.org/10.5539/jas.v2n3p229

$229-234$

Rahman, Md. M., Zahan, F., Sikdar, Md. SI., EL Sabagh, A., Barutçular, C., Islam, M. S., Ratnasekera, D. (2017). Evaluation of salt tolerance mung bean genotypes and mitigation of salt stress through potassium nitrate fertilization. Fresenius Environmental Bulletin, 26(12), 7218-7226.

Willey, R. W. (1990). Resource use in intercropping system. Agricultural Water Management, 17, 215231. doi.org/10.1016/0378-3774(90)90069-B

Willey, R. W., Rao, R. M. (1980). A competitive ratio for quantifying competition between intercropping. Experimental-Agriculture, l6(1), 117-125. doi : 10.1017/S0014479700010802

Yilmaz, S., Atak, M., Erayman, M. (2008). Identification of advantage of maize-legume intercropping over solitary cropping through competition indices in the east Mediterranian region. Turkish Journal of Agriculture and Forestry, 3q`2, 111-119. 